\title{
Comparison of Long-Term Survival Rates of Primary Surgery and Surgery After Neoadjuvant Chemotherapy in Ovarian Cancer
}

\section{Over Kanserinde Neoadjuvan Kemoterapi Sonrası Cerrahi ile Primer Cerrahinin Uzun Dönem Sağkalımların Karşılaștırılması}

\author{
(D) Alpaslan Kaban11, (1) Samet Topuz², (1) Hamdullah Sözen², (1) Yavuz Salihoğlu² \\ 1 istanbul Training and Research Hospital, Clinic of Gynecological Oncology, İstanbul, Turkey \\ 2istanbul University Faculty of Medicine, Department of Gynecological Oncology, Istanbul, Turkey
}

\begin{abstract}
Introduction: To compare long-term survival of primary debulking surgery (PDS) and interval debulking surgery (IDS) after neoadjuvant chemotherapy (NAC) in patients with advanced ovarian cancer.

Methods: Patients who underwent debulking surgery for ovarian cancer between 2001 and 2014 were included in the study.

Results: Of 378 patients, 191 (50.5\%) underwent PDS and 187 (49.5\%) underwent IDS. Compared with PDS group, IDS was associated with higher optimal surgical performance (residual $<1 \mathrm{~cm})(83 \%$ vs $65 \%, \mathrm{p}<0.001)$, lower visible tumor rate in the upper abdomen during surgery $(12 \%$ vs $46 \%, p<0.001)$, lower intraabdominal ascites rate $(2 \%$ vs $64 \%, p<0.001)$, lower postoperative (within 30 days) mortality (0 vs 5) and lower bowel resection/colostomy rate ( $3 \%$ vs $11 \%, p=0.001$ ). The median follow-up period was 43 (1-161) months. Overall survival (OS) was longer in the PDS group [56.8 months $(95 \% \mathrm{Cl}$ : 48.2-65.4) vs 43.5 (95\% Cl: 38.1-48.8), log-rank test $p=0.026]$. PDS was superior in both residual subgroups, 64.9 vs 44.6 months $(p=0.008)$ in $\leq 1 \mathrm{~cm}$ group and 41.6 vs 25.3 months $(p=0.044)$ in $>1 \mathrm{~cm}$ group. The 8-year OS was higher in the PDS group (31.8\% vs $12.7 \%)$. According to multivariate Cox analysis, age, suboptimal debulking, IDS and presence of tumor in the upper abdomen were independent factors associated with shorter OS duration (hazard ratio: 1.013; 1.606; 1.456 and 1.495 , respectively).
\end{abstract}

Conclusion: NAC in patients with FIGO 2010 stage 3 ovarian cancers is useful in reducing tumor spread, surgical morbidity and suboptimal surgery rates. However, long-term survival rates were shorter than the PDS group.

Keywords: Chemotherapy, cytoreduction, FIGO, ovarian carcinoma
ÖZ

Amaç: Illeri evre over kanserli hastalarda primer debulking cerrahisi (PDS), neoadjuvan kemoterapi sonrası cerrahisi (NAC), aralıklı debulking cerrahinin (IDS) uzun dönem sağkalım açısından karşılaş̦ırılması amaçlanmıştır.

Yöntemler: 2001-2014 yılları arasında yumurtalık kanseri nedeniyle opere edilen hastalardan evre 3 olanlar çalışmaya alındı.

Bulgular: Toplam 378 hasta, 191’i (\%50,5) PDS, 187’si (\%49,5) IDS olarak ayrıldı. PDS grubu ile karşılaștırıldığında, IDS grubunda optimal cerrahi (rezidüel $<1 \mathrm{~cm}$ ) performansı daha yüksek (\%83-\%65, $\mathrm{p}<0,001)$, ameliyat sırasında üst batında makroskopik tümör görülen hasta oranı daha az (\%12-\%46, $\mathrm{p}<0,001), 1$ litreden fazla intraabdominal asit daha az (\%2$\% 64, p<0,001$ ), postoperatif (30 gün içinde) eksitus daha az (0-5), bağırsak rezeksiyonu/kolostomi oranı daha az (\%3-\%11, $p=0,001)$ izlendi. Ortanca takip süresi 43 (1-161) aydı. Genel sağkalım (GS), PDS grupta daha uzundu $[56,8$ ay (\%95 Cl: $48,2-65,4)$ vs 43,5 (\%95 Cl: 38,1-48,8), log-rank testi $p=0,026]$. Rezidüel hastalık $\leq 1 \mathrm{~cm}$ ve $>1 \mathrm{~cm}$ olan her iki alt grupta PDS üstündü (sırasıyla 64,9 ay 44,6, p=0,008; 41,6-25,3, p=0,044). 8 yıllık GS oranı, PDS hastalarında daha yüksekti (\%31,8'e karşılık \%12,7). Çok değişkenli Cox analizine göre, yaş, suboptimal cerrahi, IDS ve üst batın bölgesindeki tümör varlığı, kısa GS süresi ile ilișkili bağımsız faktörlerdi (sırasıyla tehlike oranı: $1,013 ; 1,606 ; 1,456$ ve 1,495$)$.

Sonuç: FIGO evre 3 over kanserli hastalarda neoadjuvantkemoterapi, tümör yayılımını azaltmada, cerrahi morbiditeyi azaltmada ve optimal storedüksiyonun azaltılmasında yararlıdır. Ancak uzun dönem sağkalım oranları primer cerrahi grubuna göre daha kısa bulundu.

Anahtar Kelimeler: Kemoterapi, sitoredüksiyon, FIGO, yumurtalık karsinomu 88-93. 


\section{Introduction}

Three-quarters of patients with ovarian cancer are diagnosed with advanced-stage disease (FIGO 2010 stage 3/4) at presentation. Primary debulking surgery (PDS) followed by chemotherapy with paclitaxel and carboplatin, and neoadjuvant chemotherapy (NAC) followed by interval debulking surgery (IDS) are two main treatment approaches $(1,2)$. According to randomized controlled trials, survival is similar for both treatment approaches (3-5). These studies showed that postoperative complication rates were lower and the optimal surgery rate was higher in IDS after NAC. Therefore, over the past decade, the use of NAC has increased and PDS rates are showing a negative trend (6).

Recently, several studies have shown poorer survival in IDS compared to PDS (4,7-12).

In this study, we compared the outcomes of patients with advanced stage (FIGO stage 3) ovarian cancer treated with IDS after NAC or PDS.

\section{Methods}

The study included patients who underwent surgery for advanced stage ovarian, tubal, or peritoneal cancer at İstanbul University İstanbul Faculty of Medicine Hospital between 2001 and 2013. A total of 378 patients were evaluated retrospectively. Clinical data were obtained from medical records of the patients. Inclusion criterion was a diagnosis of advanced stage high grade (FIGO stage 3C) epithelial ovarian, tubal, or peritoneal cancer according to postoperative pathology reports. Patients were triaged to undergo PDS followed by adjuvant chemotherapy (PDS group) or to receive neoadjuvant chemotherapy with IDS (IDS group).

\section{Patients}

All patients were evaluated by a multidisciplinary team of gynaecologic oncologists, radiologists, gynaecopathologists, radiation oncologists and medical oncologists. For patient evaluation, we used magnetic resonance imaging and computerized tomography, tumor markers (CA-125, CA19-9, CEA) and computed tomography for lung examination. According to these evaluations, patients planned for primary surgery were directed to preoperative preparation. Patients planned for NAC were referred to the Department of Interventional Radiology for ascites cytology or tru-cut biopsy from tumoral tissue and directed to the NAC protocol after pathological confirmation. NAC consisted of carboplatin (area under the curve 5-6) and paclitaxel (135$175 \mathrm{mg} / \mathrm{m}^{2}$ ) every 3 weeks. The number of planned chemotherapy cycles was 3-4 prior to surgery.

As a standard surgical procedure in both groups (IDS-NAC and PDS), bilateral salpingo-oophorectomy, hysterectomy, appendectomy, and omentectomy were performed, and all visible tumors were removed if possible. Pelvic/para-aortic lymphadenectomy or sampling was performed in some patients. The decision to perform pelvic/paraaortic lymphadenectomy was determined by the surgical team. Other surgical procedures, the most common of which were large/small bowel resection and splenectomy, were performed when necessary. Optimal surgery was defined as the absence of a tumor larger than $1 \mathrm{~cm}$ at the end of the surgical procedure. After surgery, all patients were treated by the same team of medical oncologists and received the same regimen of chemotherapy (paclitaxel plus platinum-based chemotherapy).

\section{Follow-up}

All patients underwent a follow-up protocol after postoperative chemotherapy. The patients were evaluated with a gynecological examination and CA-125 markers every 3-4 months in the first two years. After two years, patients were evaluated every six months. If recurrent disease was suspected, patients were assessed by magnetic resonance imaging and by positron emission tomography, if necessary.

The overall survival (OS) was defined as the time from initial treatment to death or to the last follow-up examination. The primary endpoint of this study was OS.

The Statistical Package for the Social Sciences (SPSS) for Windows version 21 was used to perform all analyzes. Kaplan-Meier method was used for survival distributions and significance for survival duration was determined by the log-rank test. Differences between groups were analyzed using Fisher's exact and chi-square tests. P values less than 0.05 was considered significant.

Since this study is a retrospective review, the permission of the local ethics committee has not been obtained. However, all patients signed an informed consent for the use of their clinical data.

\section{Results}

A total of 378 patients, 191 in the PDS group and 187 in the IDS group, were analyzed. Clinical and survival features are presented in Table 1. During 43 months of median follow-up period, 128 (67\%) patients from the PDS group and 137 (73\%) patients from the IDS group died $(p=0.185)$. The optimal surgery rate was higher in the IDS group ( $83 \%$ vs $65 \%, p<0.001)$. The mean age was higher in the PDS group (56.3 \pm 13.2 vs $59.7 \pm 10.5)$. In the PDS group, there was more tumor in the upper abdomen ( $46 \%$ vs $12 \%, p<0.001)$, intraabdominal ascites more than 1 liter (64\% vs $2 \%, p<0.001$ ), higher lymphadenectomy rate ( $53 \%$ vs $13 \%, p<0.001)$, higher bowel resection/colostomy rate (11\% vs $3 \%, p=0.001$ ), and higher postoperative mortality (within 30 days) ( 5 vs 0 ) (Table 1).

\section{Survival Analysis}

The PDS group had a higher median OS duration than the IDS group (56.8 vs 43.5 months, log-rank test $p=0.026$ ). 2 -year OS rates were higher in the IDS group (85\% vs 77\%) and 3-year, 5-year, and 8-year OS rates were higher in the PDS group (64.3\% vs $60.6 \%, 47.1 \%$ vs $36.6 \%, 31.8 \%$ vs $12.7 \%$, respectively) (Figures $1-2$ ).

\section{Subgroup Analysis (Table 2)}

Each group was subdivided in terms of optimal surgery. OS times of subgroups based on optimality are presented in Table 2. The best survival was in the PSD group with optimal surgery (64.9 months). The IDS group undergoing suboptimal surgery had the worst survival (25.3 months). 


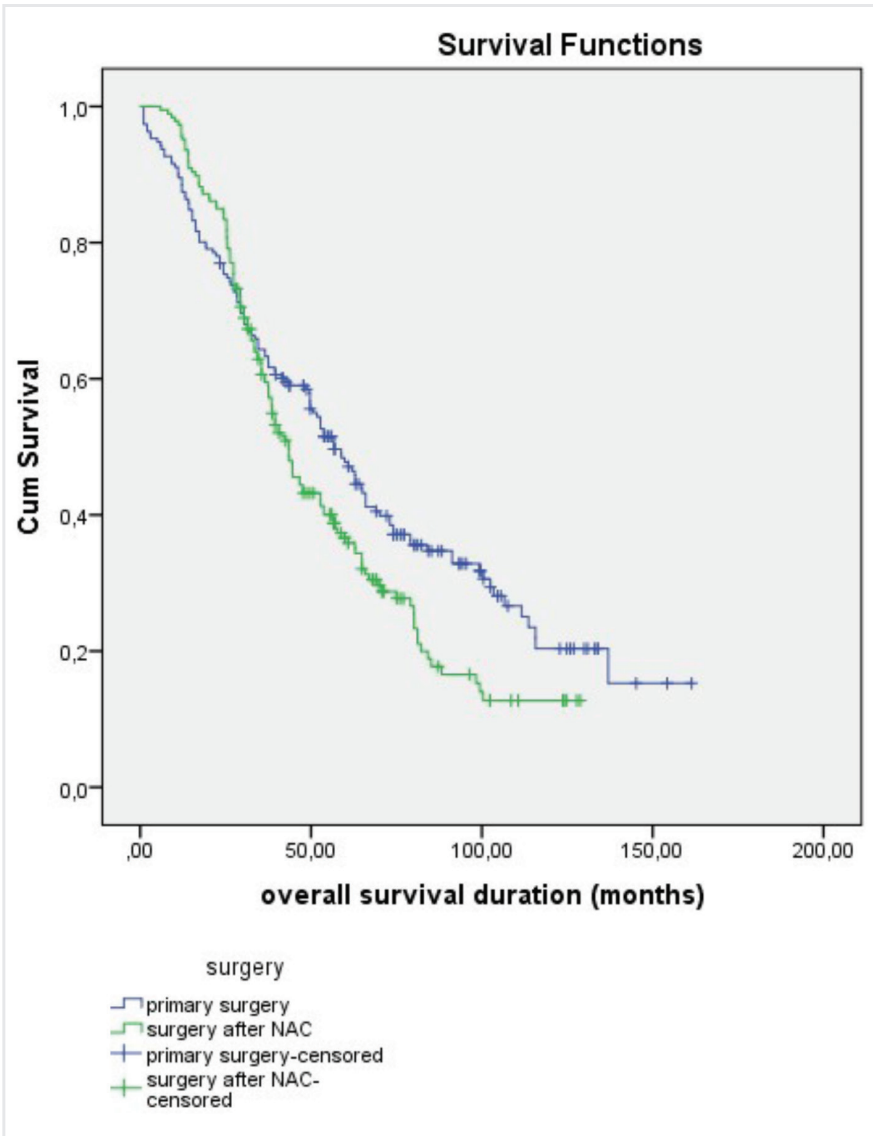

Figure 1. Overall survival of patients grouped according to neoadjuvant chemotherapy (log-rank test $\mathrm{p}=0.026$ )

NAC: neoadjuvant chemotherapy

Table 1. Clinical and survival results of patients based on PDS/IDS

\begin{tabular}{|l|l|l|l|}
\hline Feature & $\begin{array}{l}\text { Primary } \\
\text { debulking } \\
\text { surgery } \\
\text { (n=191) }\end{array}$ & $\begin{array}{l}\text { Interval } \\
\text { debulking } \\
\text { surgery } \\
\text { (n=187) }\end{array}$ & $\mathbf{p}$ \\
\hline $\begin{array}{l}\text { Age, (years) mean } \pm \text { SD } \\
>60 \text { years }\end{array}$ & $\begin{array}{l}56.3 \pm 13.2 \\
72(37.7 \%)\end{array}$ & $\begin{array}{l}59.7 \pm 10.5 \\
93(49.7 \%)\end{array}$ & $\mathbf{0 . 0 0 7}$ \\
\hline Performance of optimal surgery & $124(65 \%)$ & $156(83 \%)$ & $<\mathbf{0 . 0 0 1}$ \\
\hline Presence of visible tumor at upper & $88(46 \%)$ & $23(12 \%)$ & $<\mathbf{0 . 0 0 1}$ \\
\hline abdomen during surgery & $123(64 \%)$ & $5(2 \%)$ & $<\mathbf{0 . 0 0 1}$ \\
\hline Ascites (more than 1 liter) & $102(53 \%)$ & $24(13 \%)$ & $<\mathbf{0 . 0 0 1}$ \\
\hline Lymphadenectomy & $21(11 \%)$ & $6(3 \%)$ & $\mathbf{0 . 0 0 1}$ \\
\hline Bowel resection/colostomy & $128(67 \%)$ & $137(73 \%)$ & 0.185 \\
\hline Total exitus & $5(2.6 \%)$ & - & \\
\hline Postoperative (within 30 days) & 56.8 & 43.5 & $\mathbf{0 . 0 2 6}$ \\
\hline Median overall survival & $48.2-65.4$ & $38.1-48.8$ & \\
\hline (months) 95\% Cl & $77.0 \%$ & $85.0 \%$ & \\
\hline 2-year survival rate & $64.3 \%$ & $60.6 \%$ & \\
\hline 3-year survival rate & $47.1 \%$ & $36.6 \%$ & \\
\hline 5-year overall survival rate & $31.8 \%$ & $12.7 \%$ & \\
\hline 8-year overall survival rate & & \\
\hline 5D: sta & & \\
\hline
\end{tabular}

SD: standard deviation, Cl: confidence interval, PDS: primary debulking surgery, IDS: interval debulking surgery

\section{Cox regression analysis (Table 3 )}

Factors related to OS were analyzed by univariate and multivariate analyses (Table 3). The examined factors included age, optimal surgery, presence of tumor in the upper-abdomen, lymphadenectomy and treatment option (PDS or IDS). According to multivariate analysis, suboptimal surgery [hazard ratio (HR), 1.606; (95\% Cl, 1.184-2.177); $p=0.002]$, presence of tumor in the upper-abdomen [HR, 1.495; $(95 \% \mathrm{Cl}$, 1.113-2.006); $p=0.007$ ], IDS [HR, 1.456; (95\%Cl, 1.076-1.970); $p=0.015]$, and age [HR, 1.013; $(95 \% \mathrm{Cl}, 1.002-1.024) ; p=0.025]$ were associated with shorter survival duration. Lymphadenectomy was associated with OS in univariate analysis, but not in multivariate analysis.

\section{Discussion}

The NAC-IDS approach has been undertaken for patients with advanced stage ovarian cancer over the last 25 years, as an alternative option to PDS. This approach is increasingly preferred and the use of PDS is decreasing in clinics $(6,13)$. Comparative survey outcomes for PDS and IDS continue to be published. To date, more than 20 studies comparing survival have been published (Table 4). In some studies, NAC-IDS seems advantageous in terms of survival, whereas others have reported that the PDS approach is preferable (Table 4). However, there is consensus that IDS is superior to PDS in terms of performance of optimal debulking (12-14).

In this study, optimal debulking and absence of upper abdominal metastasis were independent positive prognostic factors according to multivariate analysis (Table 3). These factors were higher in the NAC group. Despite these good results in the NAC group, survival was lower (median OS duration was 43.5 vs 56.8 months, $p=0.026$ ) (Table 1). The survival advantage of PDS has become more prominent in the long-term survival analysis (Figures 1, 2). In addition, PDS was superior in terms of survival in subgroup analysis based on performance of optimal surgery (Table 2). Interestingly, patients with NAC have a shorter survival rate compared to patients with PDS, even though optimal surgery has been achieved. Similarly, in a recent study, Kessous et al. (15) reported that

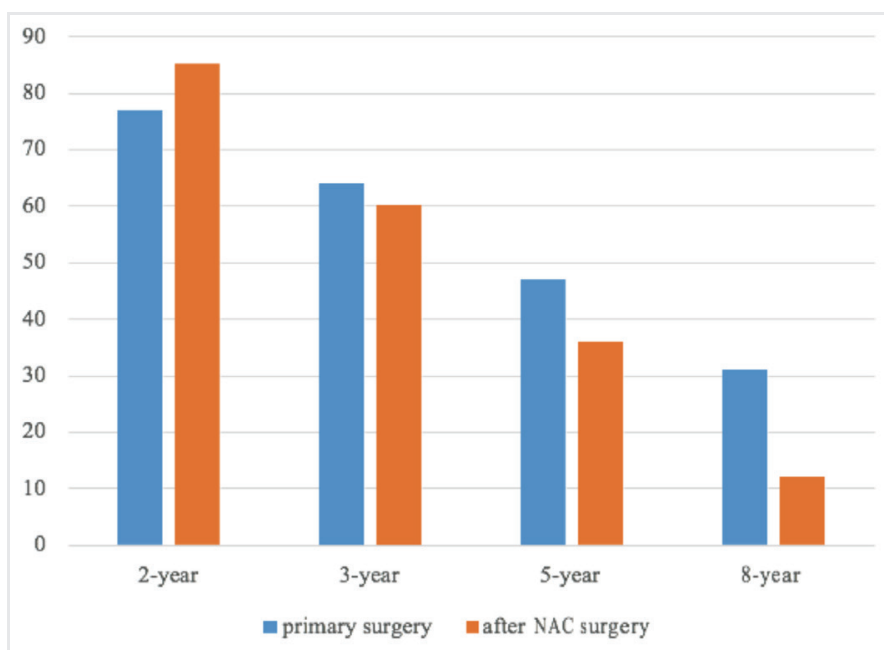

Figure 2. Comparison of overall survival rates (\%) for IDS/PDS groups at 2, 3,5 and $8^{\text {th }}$ years

IDS: interval debulking surgery, PDS: primary debulking surgery 
patients with PDS had better OS than with NAC-IDS (60 months vs 48 months, $p=0.039)$. However, complete cytoreduction rates in the PDS group were lower than in the NAC-IDS group (65.9\% vs $40.2 \%, p=0.001)$.

In another study, Rosen et al. (9) reported that optimal surgery rates in patients with PDS were lower than patients with NAC-IDS (64\% vs 79\%). However, long-term OS rates were significantly higher (seven-year survival rate $8.6 \%$ vs $41.1 \% ; \mathrm{p}<0.0001$ ) in patients with PDS. In our study, 8-year OS rates were higher in the PDS group (31.8\% vs 12.7\%) (Table 1). In this study, 2-year OS rate in IDS seems to be better (not statistically significant) and 3-year and later survival was higher in PDS. The number of patients who died in the postoperative period was higher in the primary surgery arm (5 vs 0 ). This result causes the survival of the PDS to be short in the first year.

In a recent comparative study of two groups, May et al. (16) reported that 5-year survival was better for patients undergoing PDS than in patients who received NAC (39\% vs $27 \% ; p=0.02$ ). However, the gross residual $\mathrm{tm}(>1 \mathrm{~cm})$ ratio in the PDS group was higher in their study (28\% vs $19 \%, p=0.02)$.

Many studies comparing the survival of the two groups are presented in Table 4. According to randomized controlled prospective trials, survival rates were similar in patients with advanced stage ovarian cancer who underwent NAC-IDS or PDS. Conversely, in retrospective studies, the survival of patients with PDS appears to be slightly better than that of patients with NAC-IDS (Table 4). However, optimal cytoreduction rates in PDS arms of randomized controlled trials were low. The reported rates were $42 \%$ in Vergote and $37.6 \%$ in Kehoe. This may be associated with low survival in the PDS group. Additionally, a patient eligible for PDS may have received NAC due to the randomization procedure. The main limitation in these randomized trials is that the selection process, which significantly biases the results, is usually not known.

In a recent meta-analysis, Qin et al. (17) and colleagues analyzed 22 retrospective observational studies and reported that OS was longer in the PDS group than that in the NAC group, irrespective of the degree of residual disease. Additionally, the authors stated that patients with FIGO stage 3 [HR=1.43, (95\% Cl: 1.05-1.95)] and 4 [HR=1.14, (95\% Cl: $1.06-$ 1.23)] diseases had a better survival with PDS.

Regarding the adverse effect of NAC, some authors suggest that chemotherapeutics given may facilitate the emergence of chemotherapy-resistant cancer cell clones in NAC-IDS patients $(18,19)$. Another hypothesis is that the tumor implants, which are shrinking due to chemotherapy, cannot be seen during laparotomy.

There are probably a limited number of patients who are eligible for surgery after NAC, and the criteria for this group need to be clarified. In fact, the main limitation in our study and in other studies comparing NAC and IDS is the uncertainty of patient selection criteria.

\section{Conclusion}

NAC followed by IDS appears to be worse than PDS in patients with stage 3 ovarian cancer. With NAC, tumor spread and surgical morbidity are reduced and optimal cytoreduction rates are increased. However, these positive improvements do not reflect positively on the OS of the patients.

Table 2. Analysis of overall survival of subgroups according to neoadjuvant chemotherapy and optimal surgery

\begin{tabular}{|c|c|c|c|c|c|c|}
\hline \multirow{3}{*}{ Optimality } & \multirow{3}{*}{ Surgery } & \multicolumn{4}{|c|}{ Median overall survival duration (months) } & \multirow{3}{*}{ p } \\
\hline & & \multirow{2}{*}{ Estimate } & \multirow{2}{*}{ Standard error } & \multicolumn{2}{|l|}{$95 \% \mathrm{Cl}$} & \\
\hline & & & & Lower bound & Upper bound & \\
\hline \multirow{3}{*}{ Optimal } & Primary surgery $(n=124)$ & 64.9 & 8.1 & 48.9 & 80.9 & \multirow{3}{*}{0.008} \\
\hline & Surgery after NAC $(n=156)$ & 44.6 & 3.9 & 36.9 & 52.2 & \\
\hline & Overall & 56.8 & 4.4 & 48.0 & 65.5 & \\
\hline \multirow{3}{*}{ Suboptimal } & Primary surgery $(\mathrm{n}=67)$ & 41.6 & 7.6 & 26.7 & 56.5 & \multirow{3}{*}{0.044} \\
\hline & Surgery after NAC $(n=31)$ & 25.3 & 1.6 & 22.0 & 28.6 & \\
\hline & Overall & 34.4 & 5.0 & 24.6 & 44.2 & \\
\hline Overall & Overall & 49.7 & 3.2 & 43.3 & 56.0 & \\
\hline
\end{tabular}

Table 3. Survival related factors according to multivariate and univariate cox regression analysis

\begin{tabular}{|c|c|c|c|c|c|c|c|c|}
\hline \multirow[b]{3}{*}{ Reference variabl } & \multicolumn{4}{|c|}{ Univariate analysis } & \multicolumn{4}{|c|}{ Multivarite analysis } \\
\hline & \multirow{2}{*}{ HR } & \multicolumn{2}{|l|}{$95 \% \mathrm{Cl}$} & \multirow{2}{*}{$\mathbf{p}$} & \multirow{2}{*}{ HR } & \multicolumn{2}{|c|}{$95 \% \mathrm{Cl}$} & \multirow{2}{*}{ p } \\
\hline & & Lower & Upper & & & Lower & Upper & \\
\hline Age & 1.017 & 1.006 & 1.027 & 0.002 & 1.013 & 1.002 & 1.024 & 0.025 \\
\hline Suboptimal surgery & 1.317 & 1.032 & 1.681 & 0.027 & 1.606 & 1.184 & 2.177 & 0.002 \\
\hline Presence of tumor at upper-abdomen & 1.433 & 1.110 & 1.849 & 0.006 & 1.495 & 1.113 & 2.006 & 0.007 \\
\hline Absance of lymphadenectomy & 1.707 & 1.302 & 2.237 & 0.001 & 1.766 & 0.938 & 1.736 & 0.121 \\
\hline IDS & 1.317 & 1.032 & 1.681 & 0.027 & 1.456 & 1.076 & 1.970 & 0.015 \\
\hline
\end{tabular}


Table 4. Results of studies comparing primary debulking surgery with interval debulking surgery after neoadjuvant chemotherapy in ovarian cancer

\begin{tabular}{|c|c|c|c|c|c|}
\hline Trials/year & Design & $\mathrm{n}$ & Superior & $\begin{array}{l}\text { Overall survival } \\
\text { (months) } \\
\text { IDS vs PDS }\end{array}$ & p \\
\hline Vergote et al. (4) (EORTC/NCIC trial) & Randomized controlled & 670 & - & 29.0 vs 30.0 & NS \\
\hline Kehoe et al. (20) (CHORUS) & Randomized controlled & 550 & IDS & 24.1 vs 22.6 & NS \\
\hline Shimizu et al. (21) & Retrospective & 165 & IDS & 31 vs 21 & $<0.05$ \\
\hline Scwartz et al. (22) & Retrospective & 265 & PDS & 12.8 vs 26.1 & NS \\
\hline Kuhn et al. (23) & Prospective, nonrandomized & 63 & IDS & 42 vs 23 & 0.007 \\
\hline Kayıkçioglu et al. (24) & Retrospective & 205 & PDS & 34.1 vs 37.9 & NS \\
\hline Morice et al. (25) & Retrospective & 68 & IDS & 26 vs 22 & NS \\
\hline Hegazy et al. (26) & Prospective cohort & 59 & PDS & 25 vs 28 & NS \\
\hline Loizzi et al. (27) & Retrospective & 60 & PDS & 32 vs 40 & NS \\
\hline Inciura et al. (28) & Retrospective & 574 & PDS & 23.7 vs 25.4 & NS \\
\hline Steed et al. (29) & Retrospective & 116 & PDS & 29 vs 44 & 0.03 \\
\hline Hou et al. (30) & Retrospective & 172 & PDS & 46 vs 47 & NS \\
\hline McLean et al. (31) & Retrospective & 175 & PDS+ & 29 vs 34 & NS \\
\hline Chi et al. (32) & Retrospective & 316 & PDS & 37 vs 50 & - \\
\hline Rauh-Hain et al. (33) & Retrospective & 242 & IDS++ & 33 vs 29 & NS \\
\hline Glasgow et al. (34) & Retrospective & 104 & PDSE & 25 vs 39 & NS \\
\hline Fago-Olsen et al. (8) & Retrospective & 1677 & PDS & 29.4 vs 31.9 & 0.099 \\
\hline Rosen et al. (9) & Retrospective & 326 & PDS* & $8.6 \%$ vs $41.1 \%$ & $<0.001$ \\
\hline Solmaz et al. (35) & Retrospective & 292 & PDS & 48.2 vs 57.7 & NS \\
\hline Bian et al. (36) & Retrospective & 339 & - & 25 vs 25 & NS \\
\hline Luo et al. (19) & Retrospective & 341 & PDS & 41 vs 51 & NS \\
\hline Meyer et al. (13) & Multi-institutional observational & 1538 & PDS & $\begin{array}{l}33 \text { vs } 43 \text { (IIIC) } \\
31 \text { vs } 36 \text { (IV) }\end{array}$ & $\begin{array}{l}>0.05 \text { (in } \\
\text { IIIC) }\end{array}$ \\
\hline Kessous et al. (15) & Retrospective & 263 & PDS & 48.8 vs 60.2 & 0.039 \\
\hline May et al. (16) & Retrospective & 303 & $\mathrm{PDS}^{* *}$ & $27 \%$ vs $39 \%$ & 0.02 \\
\hline Present study 2018 & Retrospective & 378 & PDS & 43 vs 56 & 0,026 \\
\hline
\end{tabular}

Ethics Committee Approval: Since this study is a retrospective review, the permission of the local ethics committee has not been obtained.

Informed Consent: All patients signed an informed consent for the use of their clinical data.

Peer-review: Externally peer-reviewed.

Author Contributions: Concept - A.K., S.T., H.S., Y.S.; Design - A.K., S.T., H.S., Y.S.; Supervision - A.K., S.T., H.S., Y.S.; Resources - A.K., S.T., H.S., Y.S.; Materials - A.K., S.T., H.S., Y.S.; Data Collection and/or Processing A.K., S.T., H.S., Y.S.; Analysis and/or Interpretation - A.K., S.T., H.S., Y.S.; Literature Search - A.K., S.T., H.S., Y.S.; Writing Manuscript - A.K., S.T., H.S., Y.S.; Critical Review - A.K., S.T., H.S., Y.S.

Conflict of Interest: No conflict of interest was declared by the authors.

Financial Disclosure: The authors declared that this study received no financial support.

\section{References}

1. Du Bois A, Pfistererz J. Future options for first-line therapy of advanced ovarian cancer. Int J Gynecol Cancer 2005; 15: 42-50.

2. Pignata S, Scambia G, Ferrandina G, Savarese A, Sorio R, Breda E, et al. Carboplatin plus paclitaxel versus carboplatin plus pegylated liposomal doxorubicin as first-line treatment for patients with ovarian cancer: The MITO-2 randomized phase III trial. J Clin Oncol 2011; 29: 3628-35.

3. Kehoe S, Hook J, Nankivell M, Jayson GC, Kitchener H, Lopes T, et al. Primary chemotherapy versus primary surgery for newly diagnosed advanced ovarian cancer (CHORUS): An open-label, randomised, controlled, non-inferiority trial. Lancet 2015; 386: 249-57.

4. Vergote I, Tropé CG, Amant F, Kristensen GB, Ehlen T, Johnson N, et al. Neoadjuvant chemotherapy or primary surgery in stage IIIC or IV ovarian cancer. N Engl J Med 2010; 363: 943-53.

5. van der Burg MEL, van Lent M, Buyse M, Kobierska A, Colombo N, Favalli G, et al. The effect of debulking surgery after induction chemotherapy on the prognosis in advanced epithelial ovarian cancer. Obstet Gynecol Surv 1995; 50: $516-8$. 
6. Leiserowitz GS, Lin JF, Tergas Al, Cliby WA, Bristow RE. Factors predicting use of neoadjuvant chemotherapy compared with primary debulking surgery in advanced stage ovarian cancerva national cancer database study. Int J Gynecol Cancer 2017; 27: 675-83.

7. Stewart J, Tone A, Jiang H, Bernardini M, Ferguson S, Laframboise S, et al. The optimal time for surgery in women with serous ovarian cancer. Can J Surg 2016; 59: 223-32

8. Fago-Olsen CL, Ottesen B, Kehlet H, Antonsen SL, Christensen IJ, Markauskas A, et al. Does neoadjuvant chemotherapy impair long-term survival for ovarian cancer patients? A nationwide Danish study. Gynecol Oncol 2014; 132: 292-8.

9. Rosen B, Laframboise S, Ferguson S, Dodge J, Bernardini M, Murphy J, et al. The impacts of neoadjuvant chemotherapy and of debulking surgery on survival from advanced ovarian cancer. Gynecol Oncol 2014; 134: 462-7.

10. Van Meurs HS, Tajik P, Hof MHP, Vergote I, Kenter GG, Mol BWJ, et al. Which patients benefit most from primary surgery or neoadjuvant chemotherapy in stage IIIC or IV ovarian cancer? An exploratory analysis of the European Organisation for Research and Treatment of Cancer 55971 randomised trial. Eur J Cancer 2013; 49: 3191-201.

11. Thrall MM, Gray HJ, Symons RG, Noel S, Flum DR, Goff BA. Neoadjuvant chemotherapy in the mdicare cohort with advanced ovarian cancer. NIH- Natl Instut Heal 2011; 123: 1-15.

12. Bristow RE, Chi DS. Platinum-based neoadjuvant chemotherapy and interval surgical cytoreduction for advanced ovarian cancer: A meta-analysis. Gynecol Oncol 2006; 103: 1070-6.

13. Meyer LA, Cronin AM, Sun CC, Bixel K, Bookman MA, Cristea MC, et al. Use and effectiveness of neoadjuvant chemotherapy for treatment of ovarian cancer. J Clin Oncol 2016; JCO681239.

14. Kang S, Nam B-H. Does neoadjuvant chemotherapy increase optimal cytoreduction rate in advanced ovarian cancer? Meta-analysis of 21 studies. Ann Surg Oncol 2009; 16: 2315-20

15. Kessous R, Laskov I, Abitbol J, Bitharas J, Yasmeen A, Salvador S, et al. Clinical outcome of neoadjuvant chemotherapy for advanced ovarian cancer. Gynecol Oncol 2017; 144: 474-9.

16. May T, Comeau R, Sun P, Kotsopoulos J, Narod SA, Rosen B GPA. A Comparison of survival outcomes in advanced serous ovarian cancer patients treated with primary debulking surgery versus neoadjuvant chemotherapy. Int J Gynecol Cancer 2017: 27: 668-74.

17. Qin M, Jin Y, Ma L, Zhang YY PL. The role of neoadjuvant chemotherapy followed by interval debulking surgery in advanced ovarian cancer: a systematic review and meta-analysis of randomized controlled trials and observational studies. Oncotarget 2017; 27: 8614-28.

18. Lim MC, Song YJ, Seo SS, Yoo CW, Kang S, Park SY. Residual cancer stem cells after interval cytoreductive surgery following neoadjuvant chemotherapy could result in poor treatment outcomes for ovarian cancer. Onkologie 2010; 33: $324-30$.

19. Luo Y, Lee M, Kim HS, Chung HH SY. Effect of neoadjuvant chemotherapy on platinum resistance in stage IIIC and IV epithelial ovarian cancer. Med 2016; 95: e47.

20. Kehoe S, Hook J, Nankivell M, Jayson GC, Kitchener H, Lopes T, et al. Articles: Primary chemotherapy versus primary surgery for newly diagnosed advanced ovarian cancer (CHORUS): an open-label, randomised, controlled, noninferiority trial. Lancet 2015; 386: 249-57.

21. Shimizu Y, Hasumi K. (Treatment of stage III and IV ovarian cancer--is neoadjuvant chemotherapy effective?). Nihon Sanka Fujinka Gakkai Zasshi 1993; 45: 1007-14
22. Schwartz PE, Rutherford TJ, Chambers JT, Kohorn El, Thiel RP. Neoadjuvant chemotherapy for advanced ovarian cancer: long-term survival. Gynecol Oncol 1999; 72: 93-9.

23. Kuhn W, Rutke S, Späthe K, Schmalfeldt B, Florack G, Hundelshausen VB, et al. Neoadjuvant chemotherapy followed by tumor debulking prolongs survival for patients with poor prognosis in International Federation of Gynecology and Obstetrics Stage IIIC ovarian carcinoma. Cancer 2001; 92: 2585-91.

24. Kayikçioglu F, Köse MF, Boran N, Calișkan E, Tulunay G. Neoadjuvant chemotherapy or primary surgery in advanced epithelial ovarian carcinoma. Int J Gynecol Cancer 2001; 11: 466-70.

25. Morice P, Brehier-Ollive D, Rey A, Atallah D, Lhommé C, Pautier P, et al. Results of interval debulking surgery in advanced stage ovarian cancer: An exposednon-exposed study. Ann Oncol 2003; 14: 74-7.

26. Hegazy MAF, Hegazi RAF, Elshafei MA, Setit AE, Elshamy MR, Eltatoongy M, et al. Neoadjuvant chemotherapy versus primary surgery in advanced ovarian carcinoma. World J Surg Oncol 2005; 3: 57.

27. Loizzi V, Cormio G, Resta L, Rossi CA, Di Gilio AR, Cuccovillo A, et al. Neoadjuvant chemotherapy in advanced ovarian cancer: a case-control study. Int J Gynecol Cancer 2005; 15: 217-23.

28. Inciura A, Simavicius A, Juozaityte E, Kurtinaitis J, Nadisauskiene R, Svedas $E$, et al. Comparison of adjuvant and neoadjuvant chemotherapy in the management of advanced ovarian cancer: a retrospective study of 574 patients. BMC Cancer 2006; 6: 153.

29. Steed H, Oza AM, Murphy J, Laframboise S, Lockwood G, De Petrillo D, et al. A retrospective analysis of neoadjuvant platinum-based chemotherapy versus up-front surgery in advanced ovarian cancer. Int J Gynecol Cancer 2006; 16 Suppl 1: 47-53.

30. Hou JY, Kelly MG, Yu H, McAlpine JN, Azodi M, Rutherford TJ, et al. Neoadjuvant chemotherapy lessens surgical morbidity in advanced ovarian cancer and leads to improved survival in stage IV disease. Gynecol Oncol 2007; 105: 211 . 7.

31. McLean KA, Shah CA, Thompson SA, Gray HJ, Swensen RE, Goff BA. Ovarian cancer in the elderly: outcomes with neoadjuvant chemotherapy or primary cytoreduction. Gynecol Oncol 2010; 118: 43-6.

32. Chi DS, Musa F, Dao F, Zivanovic O, Sonoda Y, Leitao MM, et al. An analysis of patients with bulky advanced stage ovarian, tubal, and peritoneal carcinoma treated with primary debulking surgery (PDS) during an identical time period as the randomized EORTC-NCIC trial of PDS vs neoadjuvant chemotherapy (NACT). Gynecol Oncol 2012; 124: 10-4.

33. Rauh-Hain JA, Rodriguez N, Growdon WB, Goodman a. K, Boruta DM, Horowitz NS, et al. Primary debulking surgery versus neoadjuvant chemotherapy in stage IV ovarian cancer. Ann Surg Oncol 2012; 19: 959-65.

34. Glasgow MA, Yu H, Rutherford TJ, Azodi M, Silasi DA, Santin AD, et al Neoadjuvant chemotherapy (NACT) is an effective way of managing elderly women with advanced stage ovarian cancer (FIGO Stage IIIC and IV). J Surg Oncol 2013; 107: 195-200.

35. Solmaz U, Mat E, Levent Dereli M, Turan V, Peker N, Tosun G, et al. Does neoadjuvant chemotherapy plus cytoreductive surgery improve survival rates in patients with advanced epithelial ovarian cancer compared with cytoreductive surgery alone? J Buon 2015; 20: 580-7.

36. Bian C, Yao K, Li L, Yi T ZX. Primary debulking surgery vs. neoadjuvant chemotherapy followed by interval debulking surgery for patients with advanced ovarian cancer. Arch Gynecol Obs 2016; 293: 163-8. 